\title{
Peningkatan Pengetahuan tentang Kanker Serviks pada Kader sebagai Upaya Peningkatan Cakupan Deteksi Dini Kanker Serviks
}

\author{
Increasing the Knowledge of Cadre about Cervical Cancer as an Effort to Improve Coverage of \\ Early Detection of Cervical Cancer
}

\begin{abstract}
Kartika Adyani*
Emi Sutrisminah

Hanifatur Rosyidah

Department of Midwifery, Universitas Islam Sultan Agung, Semarang, Central Java, Indonesia

email: kartika.adyani@unissula.ac.id

\section{Kata Kunci}

Kader

Kanker serviks

Pengetahuan

Keywords:

Cadre

Cervical cancer

Knowledge

Received: April 2021

Accepted: September 2021

Published: October 2021

\section{PENDAHULUAN}

Kanker menjadi salah satu penyebab utama kematian di dunia. Kanker yang banyak menyerang wanita adalah kanker payudara, kolorektum, paru-paru, serviks,dan kanker perut (McGuire, 2016). Kanker serviks merupakan keganasan ginekologi yang paling umum menyerang wanita dengan angka kejadian dan kematian
\end{abstract} https://doi.org/10.33084/pengabdianmu.v6i6.2218

\begin{abstract}
Abstrak
Kanker serviks masih menjadi momok bagi perempuan di dunia. Rendahnya cakupan deteksi dini kanker serviks menjadi salah satu penyebab tingginya kematian karena terlambatnya penanganan. Salah satu faktor yang mempengaruhi keikutsertaan wanita usia subur dalam deteksi dini kanker serviks adalah akses informasi dan peran kader. Tujuan dari pengabdian masyarakat ini adalah untuk meningkatkan pengetahuan kader kesehatan tentang deteksi dini kanker serviks sebagai bekal promosi kesehatan kepada wanita usia subur. Metode yang digunakan dalam kegiatan ini adalah pendidikan masyarakat melalui ceramah, tanya jawab dan diskusi. Peserta kegiatan ini adalah kader kesehatan Desa Sumberrahayu Kecamatan Limbangan yang berjumlah 13 orang. Hasil dari pengabdian terdapat peningkatan prosentase pengetahuan kategori baik (15,5\% ke 76,9\%). Peningkatan pengetahuan kader dapat dijadikan model pemberdayaan masyarakat dalam meningkatkan pengetahuan wanita usia subur tentang deteksi dini kanker serviks.
\end{abstract}

\begin{abstract}
Cervical cancer is still a scourge for women in the world. The low coverage of early detection of cervical cancer is one of the causes of high mortality due to late treatment. One factor influencing women's participation of childbearing age in cervical cancer early detection is access to information and cadres' role. This community service aims to increase the knowledge of health cadres about early detection of cervical cancer as a requirement for health promotion to women. The methods used in this activity were lectures, question and answer, and discussion. The participants were 13 health cadres in Sumberrahayu Village, Limbangan District. The result is an increase in good category knowledge (15.5 to 76.9\%). Increasing cadres' knowledge can be used as a model for community empowerment in upgrading the childbearing age women's knowledge about early detection of cervical cancer.
\end{abstract}

(C) 2021 Kartika Adyani, Emi Sutrisminah, Hanifatur Rosyidah. Published by Institute for Research and Community Services Universitas Muhammadiyah Palangkaraya. This is Open Access article under the CC-BYSA License (http://creativecommons.org/licenses/by-sa/4.0/).

yang tinggi pada wanita paruh baya (Meng et al., 2021).

Lebih dari setengah juta wanita di dunia terdiagnosis kanker serviks setiap tahunnya. Kanker tersebut menyebabkan lebih dari 300.000 kematian di seluruh dunia (Cohen et al., 2019).

Kematian yang diakibatkan oleh kanker di negara maju lebih rendah dibandingkan dengan angka kematian di negara berkembang, hal ini disebabkan oleh berbedanya 
faktor resiko, cakupan deteksi dini serta kelengkapan pengobatan (Torre et al., 2015). Kematian akibat kanker serviks di negara berkembang juga disebabkan oleh kurangnya perawatan (Small Jr. et al., 2017). Estimasi kanker serviks di Indonesia yang didapatkan dari Data Riset Kesehatan Dasar 2013 Jawa Tengah menduduki peringkat ke-2 di Indonesia dengan estimasi 19.734 kasus setelah Jawa Timur dengan estimasi 21.313 kasus di tahun 2013 (Kementerian Kesehatan Republik Indonesia, 2015). Hampir semua kanker serviks diakibatkan oleh infeksi human papillomavirus dan cara untuk mencegahnya adalah dengan deteksi dini dan vaksin (Small Jr. et al., 2017).

Cakupan deteksi dini kanker serviks di Indonesia masih rendah, hal tersebut dapat menjadi penyebab terlambatnya penanganan, karena mereka datang sudah dalam keadaan bergejala dan terdeteksi dalam kanker stadium lanjut (Dyanti \& Suariyani, 2016). Deteksi dini kanker serviks pada wanita berusia 21-65 tahun mengurangi kejadian dan kematian akibat kanker serviks (Curry et al., 2018). Deteksi dini kanker serviks dapat dilakukan dengan berbagai metode antara lain Pap Smear dan IVA test. IVA test menjadi pilihan pemeriksaan deteksi dini di Indonesia karena lebih mudah, murah, cepat serta cukup akurat dalam mendeteksi kelainan sel atau pra kanker (Adyani \& Realita, 2020). Mendukung pemeriksaan IVA test sebagai metode deteksi dini lesi pra kanker serviks merupakan salah satu upaya preventif terhadap kanker serviks di Indonesia (Dewi, 2017).

IVA test dapat dilakukan di tempat pelayanan dasar seperti Puskesmas, test ini hanya menggunakan alat sederhana yaitu larutan asam asetat 3-5\%. Apabila hasil IVA test menunjukkan kondisi pra kanker pada pasien, pengobatan akan bisa segera dilakukan untuk menghindari kondisi stadium lanjut (Sukmawati et al., 2020). Puskesmas Limbangan Kendal merupakan salah satu Puskesmas yang telah aktif menggalakkan IVA test sebagai bentuk deteksi dini kanker serviks. Pandemi Covid-19 tidak menjadi penghalang keberlangsungan pelayanan kesehatan reproduksi diantaranya adalah deteksi dini kanker serviks.

Hasil penelitian yang dilakukan oleh Adyani dan Realita menunjukkan bahwa dari 236 responden dengan kriteria wanita usia subur yang telah menikah lebih dari 5 tahun di wilayah Puskesmas Cepiring Kendal, hanya 2,9\% responden (7 orang) yang pernah melakukan pemeriksaan IVA dan salah satu variabel yang berhubungan signifikan dengan keikutsertaan dalam pemeriksaan deteksi dini kanker serviks metode IVA adalah akses informasi (Adyani \& Realita, 2020). Penelitian Susanti menunjukkan bahwa kader berperan dalam keikutsertaan wanita usia subur dalam kunjungan IVA. Peran kader yang baik akan berdampak positif juga untuk masyarakat (Susanti, 2011).

Hal tersebut menjadi salah satu dasar kegiatan pengabdian kepada masyarakat "Peningkatan Pengetahuan tentang kanker serviks pada kader sebagai upaya peningkatan cakupan deteksi dini kanker serviks". Kegiatan ini bertujuan untuk meningkatkan pengetahuan kader kesehatan tentang deteksi dini kanker serviks sebagai bekal promosi kesehatan dalam mengajak wanita usia subur untuk melakukan deteksi dini kanker seviks.

\section{METODOLOGI}

Kegiatan pengabdian kepada masyarakat dilakukan dengan beberapa tahap yaitu persiapan, pelaksanaan, dan evaluasi. Proses persiapan kegiatan yang dilakukan meliputi pengumpulan data untuk mengetahui kebutuhan mitra. Teknik yang digunakan dalam pengumpulan data adalah wawancara dengan Bidan Desa setempat. Wawancara tersebut dilakukan untuk memahami permasalahan yang dialami oleh calon 
peserta pengabdian kepada masyarakat sehingga bisa mendapatkan informasi tentang kebutuhan yang diharapkan dapat membantu memecahkan masalah.

Wawancara dilakukan sebanyak satu kali kepada Bidan Desa dengan mencari tahu hambatan proses promosi kesehatan. Berdasarkan hasil wawancara, penulis memperoleh informasi bahwa permasalahan yang ada dapat dipecahkan melalui penyuluhan kesehatan kepada kader untuk meningkatkan pengetahuan kader serta mengajak kader untuk mempromosikan kesehatan khususnya deteksi dini kanker serviks kepada masyarakat. Penulis menggunakan studi pustaka dalam mempersiapkan materi yang akan diberikan.

Kegiatanpengabdian kepada masyarakat yang berjudul peningkatan pengetahuan tentang kanker serviks pada kader sebagai upaya peningkatan cakupan deteksi dini kanker serviks ini mempertimbangkan materi penyuluhan yang dapat diaplikasikan langsung oleh kader untuk masyarakat di sekitar mereka, materi yang disajikan ringan dan mudah di pahami oleh kader.

Metode yang digunakan dalam pelaksanaan pengabdian kepada masyarakat ini adalah pendidikan masyarakat dengan cara:

1. Metode ceramah dengan memberikan gambaran umum pemeriksaan deteksi dini kanker serviks, pentingnya deteksi dini, dan peran kader dalam meningkatkan keikutsertaan wanita usia subur di lingkungannya dalam pemeriksaan deteksi dini kanker serviks.

2. Pre dan post test digunakan untuk mengukur peningkatan pengetahuan peserta.

3. Diskusi dan tanya jawab dengan memberikan kesempatan kepada peserta penyuluhan untuk menyampaikan pertanyaannya tentang materi yang belum dimengerti, lalu mengulas kembali materi tersebut melalui diskusi.

\section{HASIL DAN PEMBAHASAN}

Penulis melakukan pengabdian kepada masyarakat dengan sasaran kader kesehatan Desa Sumberrahayu. Kader kesehatan yang hadir dalam kegiatan ini berjumlah 13 orang. Pengabdian kepada masyarakat yang dilakukan bertemakan penyuluhan kesehatan tentang pentingnya deteksi dini kanker serviks menggunakan metode ceramah, dan tanya jawab. Data sosiodemografi peserta disajikan pada Tabel I. Berdasarkan tabel sosiodemografi kader kesehatan, menunjukkan bahwa $61,5 \%$ merupakan usai reproduktif, 69,2\% peserta tidak bekerja, dan 53,8\% memiliki pendidikan terakhir SMA.

Tabel I. Data Sosiademografi Kader Kesehatan

\begin{tabular}{llcc}
\hline \multicolumn{1}{c}{ Data Demografi } & $\begin{array}{c}\text { Frekuensi } \\
(\mathbf{n = 1 3 )}\end{array}$ & $\begin{array}{c}\text { Presentase } \\
\mathbf{( \% )}\end{array}$ \\
\hline Usia & 20-35 tahun & 8 & 61,5 \\
Pekerjaan & $>35$ tahun & 5 & 38,5 \\
& Tidak & 9 & 69,2 \\
& bekerja/IRT & & \\
& Petani & 3 & 23,0 \\
\multirow{5}{*}{ Pendidikan } & Swasta & 1 & 7,7 \\
& SD & 3 & 23,1 \\
& SLTP & 3 & 23,1 \\
& SMA & 7 & 53,8 \\
& Diploma/ & 0 & 0 \\
& sarjana & & \\
\hline
\end{tabular}

Peserta mengisi kuesioner pengetahuan sebelum materi diberikan. Materi diberikan dengan metode ceramah setelah pre-test selesai dikerjakan. Materi yang disampaikan mencakup pengenalan organ reproduksi wanita, kanker serviks, deteksi dini kanker serviks, dan peran kader dalam deteksi dini kanker serviks.

Pengenalan organ reproduksi wanita meliputi organ genitalia eksterna dan organ genitalia interna. Materi kanker serviks berisi tentang pengertian, penyebab, angka kejadian, gejala, dan faktor resiko. Deteksi dini kanker serviks yang disampaikan adalah metode IVA test dan PAPSmear yang meliputi pengertian, prosedur tindakan, dan persiapan menjelang pemeriksaan. Peran kader dalam deteksi dini kanker serviks di sampaikan di akhir materi. Materi tersebut memuat peran kader 
kesehatan dalam upaya meningkatkan cakupan pelaksanaan deteksi dini kanker serviks untuk meningkatkan derajat kesehatan wanita salah satunya dengan cara secara aktif mengajak ibu-ibu untuk melakukan pemeriksaan deteksi dini kanker serviks dan memberikan contoh dalam melakukan deteksi dini kanker serviks secara rutin.

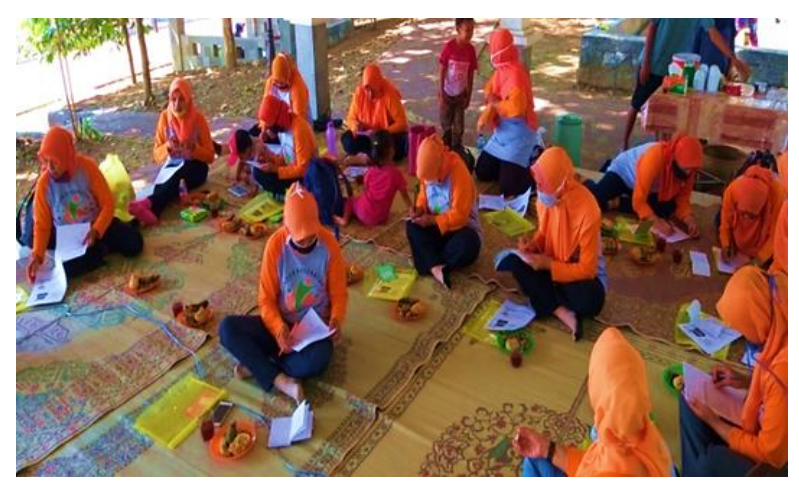

Gambar 1. Peserta mengisi Pretest

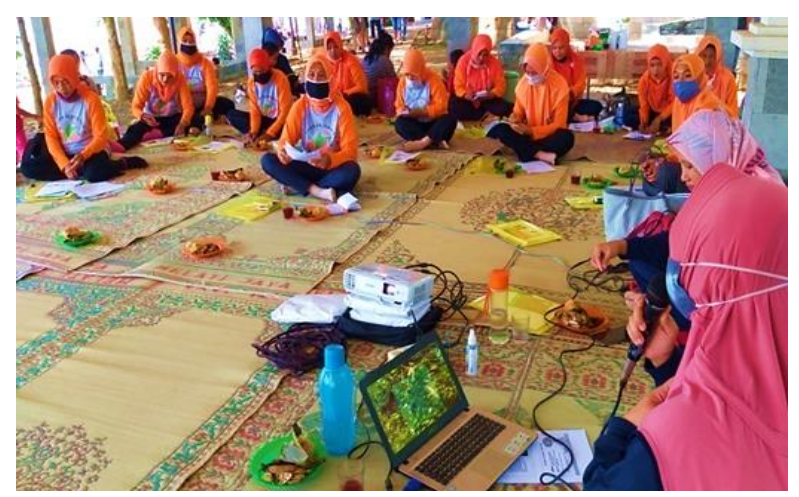

Gambar 2. Peserta Menyimak Materi Penyuluhan

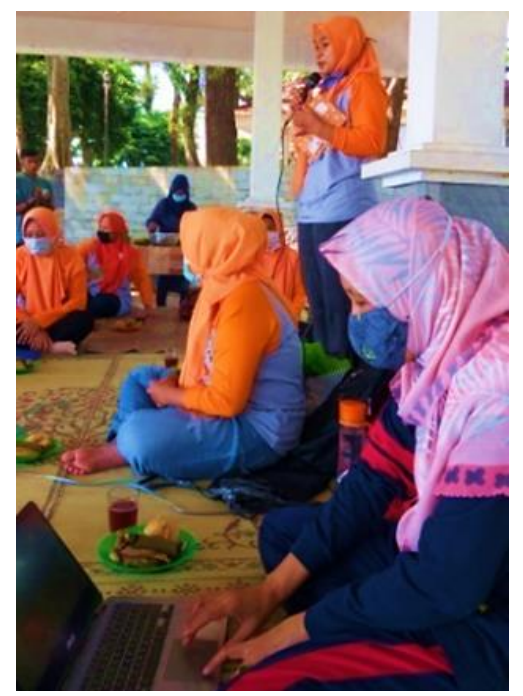

Gambar 3. Peserta aktif bertanya
Ketika penulis menyampaikan materi para peserta antusias untuk menyimak, aktif bertanya, dan menyampaikan kesannya tentang materi yang diberikan. Diantara mereka juga menceritakan pengalaman mereka dalam melakukan pemeriksaan PapSmear sebagai salah satu deteksi dini kanker serviks. Penyuluhan yang diberikan kepada kader kesehatan memiliki pengaruh yang signifikan terhadap tingkat pengetahuan peserta pelatihan. Hal tersebut terlihat dari hasil post test yang diberikan serta wawancara dengan salah satu peserta pelatihan. Peserta tersebut menyampaikan bahwa dia senang mendapatkan materi yang di sampaikan, materi tersebut dapat bermanfaat bagi dirinya dan dia akan berupaya untuk mempromosikan deteksi dini kanker serviks dengan bekal materi tersebut. Hasil perbandingan pretest dan posttest dapat terlihat dalam Tabel II.

Tabel II. Pengetahuan Kader sebelum dan sesudah penyuluhan

\begin{tabular}{lcccc}
\hline \multirow{3}{*}{ Pengetahuan } & \multicolumn{2}{c}{ Sebelum } & \multicolumn{2}{c}{ Sesudah } \\
\cline { 2 - 5 } & Frekuensi & $\begin{array}{c}\text { Presentase } \\
\mathbf{( \% )}\end{array}$ & Frekuensi & $\begin{array}{c}\text { Presentase } \\
\mathbf{( \% )}\end{array}$ \\
\hline Baik & 2 & 15,4 & 10 & 76,9 \\
Kurang & 11 & 84,6 & 3 & 23,1 \\
\hline Jumlah & 13 & 100 & 13 & 100 \\
\hline
\end{tabular}

Peserta terlihat aktif dan bersemangat selama kegiatan berlangsung. Bidan Desa selaku narahubung penulis dengan kader memberikan apresiasi kegiatan ini dan menginformasikan kemajuan keinginan peran serta kader kesehatan dalam membantu mensosialisasikan pemeriksaan deteksi dini kanker serviks. Ujung tombak dari pelayanan kesehatan di tingkat komunitas adalah kader kesehatan, peran kader diharapkan dapat menunjang kesuksesan program kesehatan yang di lakukan oleh Puskesmas (Yuhanah et al., 2019). Penelitian yang dilakukan oleh Tse et al. menunjukkan bahwa hambatan dalam melaksanakan kegiatan pembangunan masyarakat adalah pendidikan kader yang masih kurang dan pelatihan yang didapatkan belum maksimal (Tse et al., 2017). 
Penilaian pengetahuan kader sebelum pemberian materi melalui kuesioner dengan pertanyaan mengenai deteksi dini kanker serviks mendapatkan hasil bahwa hanya 2 kader yang memiliki pengetahuan baik. Pengetahuan kader yang kurang saat pre test terbanyak berada pada aspek tanda kanker serviks dan pesiapan pelaksanaan deteksi dini kanker serviks, pada hasil posttest yang telah dilakukan terlihat perubahan nilai pada point tersebut yang menunjukkan bahwa kader sudah memahami tanda kanker serviks dan hal apa saja yang perlu dipersiapkan sebelum pelaksanaan pemeriksaan.

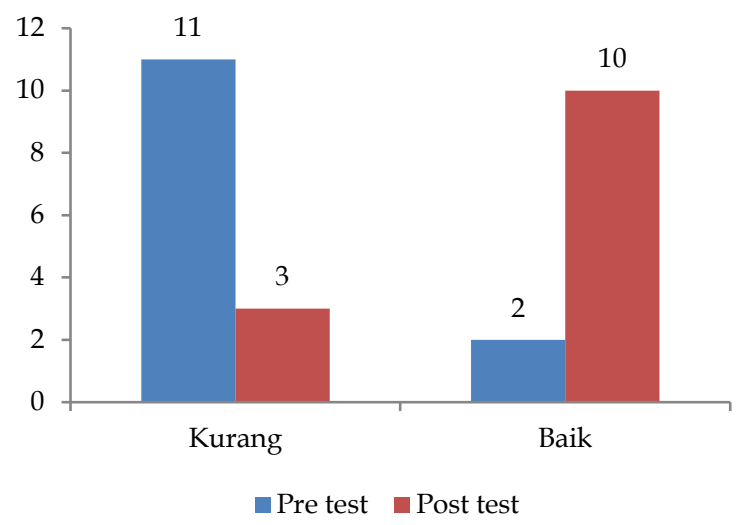

Gambar 4. Pengetahuan Kader sebelum dan sesudah penyuluhan

Secara keseluruhan terjadi peningkatan pengetahuan yang terlihat dari peningkatan jumlah kader pada kategori pengetahuan baik pada nilai post test. Pada pre test hanya ada 2 kader yang masuk dalam kategori pengetahuan baik, dan setelah materi diberikan, meningkat menjadi 10 kader yang memiliki pengetahuan baik. Kegiatan pelatihan dapat meningkatkan pengetahuan, salah satu penentu keberhasilan pemahaman peserta pelatihan dalam pemaparan materi adalah materi mudah dimengerti.

Hal ini sejalan dengan hasil pengabdian yang dilakukan oleh Budiono dan Pertami bahwa terdapat peningkatan pengetahuan kader sebelum dan sesudah mengikuti training full-blooded back sebagai metode untuk mengatasi penyakit lansia (Budiono \& Pertami, 2019). Pengabdian lain yang menunjukkan peningkatan pengetahuan setelah diadakan kegiatan pengabdian adalah pengabdian Masrikhiyah yang menyimpulkan bahwa terjadi peningkatan pengetahuan ibu mengenai gizi seimpang pada kegiatan pengabdian masyarakat dengan judul peningkatan pengetahuan ibu mengenai gizi seimbang dalam pemenuhan gizi keluarga (Masrikhiyah, 2020). Pelatihan yang diberikan kepada kader kesehatan merupakan salah satu bentuk imbalan jasa berbentuk non finansial berupa informasi yang dapat digunakan untuk kemajuan diri, keluarga, dan masyarakat (Mediani et al., 2020). Informasi baru dapat meningkatkan pengetahuan seseorang, informasi tersebut dapat menjadi penyempurna informasi sebelumnya ataupun pengganti informasi yang sudah pernah didapatkan (Lubis, 2015).

Salah satu hambatan dalam deteksi dini kanker serviks adalah kurangnya informasi, hal tersebut ditunjukkan oleh penelitian yang dilakukan oleh Adyani dan Realita bahwa salah satu variabel yang berhubungan signifikan dengan keikutsertaan wanita usia subur dalam pemeriksaan deteksi dini kanker serviks metode IVA adalah akses informasi (Adyani \& Realita, 2020). Hal serupa dibuktikan dengan penelitian yang dilakukan oleh Sinaga bahwa pengetahuan mempengaruhi upaya wanita usia reproduktif dalam pencegahan kanker serviks (Sinaga, 2020). Pelatihan yang diberikan diharapkan dapat menjadi sumber informasi untuk meningkatkan pengetahuan para kader agar dapat meningkatkan peran serta kader kesehatan dalam meningkatkan kesadaran masyarakat akan pentingnya deteksi dini kanker serviks.

Salah satu hal yang menjadi hambatan dalam pengabdian masyarakat ini adalah jumlah peserta yang harus dibatasi karena pandemi Covid-19. Akibatnya tidak semua kader kesehatan mengikuti acara yang diselenggarakan. Peserta yang hadir terlihat 
bersemangat dan menyimak dengan seksama materi yang disampaikan. Partisipasi aktif kader kesehatan dalam upaya pencegahan dan deteksi dini kanker serviks melalui upaya promosi kesehatan tentang kanker serviks kepada masyarakat dapat dijadikan model pemberdayaan masyarakat di bidan kesehatan sehingga diharapkan tidak lagi ditemui kurangnya informasi tentang deteksi dini kanker serviks dan dapat meningkatkan peran serta wanita usia subur dalam deteksi dini kanker serviks yang dapat mengurangi resiko keterlambatan penanganan kanker serviks.

\section{KESIMPULAN}

Pelatihan dalam rangka meningkatkan pengetahuan kader sebagai tenaga promosi kesehatan Puskesmas Limbangan ini telah mencapai tujuan yang diharapkan yaitu meningkatkan pengetahuan kader Kesehatan tentang deteksi dini kanker serviks sebagai bekal promosi kesehatan kepada wanita usia subur. Hasil ini dapat dilihat dari hasil pengukuran pengetahuan sebelum dan sesudah materi diberikan. Pengetahuan pada kategori baik meningkat dari 15, 5\% peserta menjadi 76,9 \% peserta. Saran untuk Puskesmas Limbangan adalah meningkatkan dukungan kepada kader kesehatan dengan cara meningkatkan pengetahuan dan keterampilan kader kesehatan terkait dengan kesehatan ibu melalui kegiatan seminar atau pun pelatihan.

\section{UCAPAN TERIMA KASIH}

Terimakasih penulis sampaikan untuk LPPM UNISSULA yang telah membiayai pelaksanaan pengabian masyarakat ini.

\section{REFERENSI}

Adyani, K., Realita, F. 2020. Factors that influence the participation among women in Inspection
Visual Acetic acid (IVA) test. Jurnal Aisyah: Jurnal Ilmu Kesehatan. 5(2):115-121. https://doi.org/10.30604/jika.v5i2.289

Budiono, Pertami, S.B. 2019. Pemberdayaan Peran Kader Dalam Meningkatkan Kesehatan Lansia Melalui Terapi Totok Punggung di BKL (Bina Keluarga Lansia) Kecamatan Lawang. In Prosiding Seminar Nasional Hasil Penelitian dan Pengabdian kepada Masyarakat Seri 3: Strategi Kebijakan Pemerintah dalam Mendukung Revolusi Industri 4.0 di Bidang Kesehatan Menuju Pencapaian SDGs (Sustainable Development Goals). Mojokerto: Sekolah Tinggi Ilmu Kesehatan Majapahit. pp. 30-39.

Cohen, P.A., Jhingran, A., Oaknin, A., Denny, L. 2019. Cervical cancer. Lancet. 393(10167):169-182. https://doi.org/10.1016/S01406736(18)32470-X

Curry, S.J., Krist, A.H., Owens, D.K., Barry, M.J., Caughey, A.B., Davidson, K.W., Doubeni, C.A., Epling Jr., J.W., Kemper, A.R., Kubik, M., Landefeld, C.S., Mangione, C.M., Phipps, M.G., Silverstein, M., Simon, M.A., Tseng, C.W., Wong, J.B. 2018. Screening for cervical cancer: US Preventive Services Task Force recommendation statement. JAMA. 320(7):674-686.

https://doi.org/10.1001/jama.2018.10897

Dewi, M. 2017. Sebaran Kanker di Indonesia, Riset Kesehatan Dasar 2007. Indonesian Journal of Cancer. 11(1):1-8. http://dx.doi.org/10.33371/ijoc.v11i1.494

Dyanti, G.A.R., Suariyani, N.L.P. 2016. Faktor-Faktor Keterlambatan Penderita Kanker Payudara Dalam Melakukan Pemeriksaan Awal Ke Pelayanan Kesehatan. KEMAS: Jurnal Kesehatan Masyarakat. 11(2):276-284. https://doi.org/10.15294/kemas.v11i2.3742

Kementerian Kesehatan Republik Indonesia. 2015. Situasi Penyakit Kanker. Jakarta: Pusat Data dan Informasi Kementerian Kesehatan Republik Indonesia.

Lubis, Z. 2015. Pengetahuan dan tindakan kader posyandu dalam pemantauan pertumbuhan anak balita. KEMAS: Jurnal Kesehatan Masyarakat. $\quad \mathbf{1 1 ( 1 ) : 6 5 - 7 3 . ~}$ https://doi.org/10.15294/kemas.v11i1.3473 
Masrikhiyah, R. 2020. Peningkatan Pengetahuan Ibu Mengenai Gizi Seimbang Dalam Pemenuhan Gizi Keluarga. Dinamisia: Jurnal Pengabdian Kepada Masyarakat. 4(3):476-481. https://doi.org/10.31849/dinamisia.v4i3.363 6

McGuire, S. 2016. World cancer report 2014. Geneva, Switzerland: World Health Organization, international agency for research on cancer, WHO Press, 2015. Advances in Nutrition. 7(2):418-419.

https://doi.org/10.3945/an.116.012211

Mediani, H.S., Nurhidayah, I., Lukman, M. 2020. Pemberdayaan Kader Kesehatan tentang Pencegahan Stunting pada Balita. Media Karya Kesehatan. 3(1):82-90. https://doi.org/10.24198/mkk.v3i1.26415

Meng, Q., Zhang, B., Zhang, Y., Wang, S., Zhu, X. 2021. Human bone marrow mesenchymal stem cellderived extracellular vesicles impede the progression of cervical cancer via the miR-1443p/CEP55 pathway. Journal of Cellular and Molecular Medicine. 25(4):1867-1883. https://doi.org/10.1111/jcmm.15573

Sinaga, S.P. 2020. Hubungan Pengetahuan dan Karakteristik Wanita Usia Reproduksi Terhadap Upaya Pencegahan Kanker Serviks Melalui Skrining IVA Test di Puskesmas BiruBiru Tahun 2019. Jurnal Kesehatan Masyarakat dan Lingkungan Hidup. 5(2):55-63.

Small Jr, W., Bacon, M.A., Bajaj, A., Chuang, L.T., Fisher, B.J., Harkenrider, M.M., Jhingran, A., Kitchener, H.C., Mileshkin, L.R., Viswanathan, A.N., Gaffney, D.K. 2017. Cervical cancer: a global health crisis. Cancer. 123(13):2404-2412. https://doi.org/10.1002/cncr.30667

Suartini, N. W. (2013). Pengetahuan dan motivasi wanita pasangan usia subur tentang tes IVA di Propinsi Bali Indonesia. Artikel Ilmiah, Vol. 24. No. 2. Hal. 125-140.

Sukmawati, S., Mamuroh, L., Nurhakim, F. 2020. Pendidikan Kesehatan dan Pelaksanaan Iva Test pada Wanita Usia Subur. Media Karya Kesehatan. https://doi.org/10.24198/mkk.v3i1.24916

Susanti, A. 2011. Faktor-Faktor Yang Berhubungan Dengan Rendahnya Kunjungan Inspeksi Visual Asam Asetat di Wilayah Kerja puskesmas Halmahera Kecamatan Semarang Timur Tahun 2014. Skripsi. Semarang: Universitas Negeri Semarang.

Torre, L.A., Bray, F., Siegel, R.L., Ferlay, J., Lortet-Tieulent, J., Jemal, A. 2015. Global cancer statistics, 2012. CA: A Cancer Journal for Clinicians. 65(2):87-108. https://doi.org/10.3322/caac.21262

Tse, A.D.P., Suprojo, A., Adiwidjaja, I. 2017. Peran kader posyandu terhadap pembangunan kesehatan masyarakat. JISIP: Jurnal Ilmu Sosial Dan Ilmu Politik. https://doi.org/10.33366/jisip.v6i1.372

Yuhanah, Y., Nuridah, N., Yodang, Y. 2019. Pemberdayaan Kader Kesehatan Dalam Skrining dan Deteksi Dini Kanker Payudara Melalui Breast Self-Examination. Jurnal Penelitian dan Pengabdian Kepada Masyarakat UNSIQ. 6(3):143-149. https://doi.org/10.32699/ppkm.v6i3.746 